\title{
Jan Joosten*
}

\section{Pseudo-Classicisms in Late Biblical Hebrew}

DOI 10.1515/zaw-2016-0003

\section{Prolegomena}

Languages change over time, and so does Hebrew during the period when the biblical writings were composed. ${ }^{1}$ To a linguist, the study of Biblical Hebrew in diachronic perspective is exciting. The history of Biblical Hebrew demonstrates that it is a real language, evolving along typologically predictable lines. ${ }^{2}$ It is not an artificial construct, created as a kind of Esperanto for sacred affairs. ${ }^{3}$ To a philologist, diachronic study of Hebrew is indispensable. Words and constructions

1 The first scholar explicitly drawing attention to developments in Biblical Hebrew is Elias Levita who points out that books relating to the Persian period have far more Aramaisms than other biblical books. However, a comprehensive historical view of Biblical Hebrew is achieved only by Wilhelm Gesenius at the beginning of the nineteenth century. See Jan Joosten, »Wilhelm Gesenius and the history of Hebrew in the Biblical period, « in Biblische Exegese und hebräische Lexikographie. Das »Hebräisch-deutsche Handwörterbuch « von Wilhelm Gesenius als Spiegel und Quelle alttestamentlicher und hebräischer Forschung, 200 Jahre nach seiner ersten Auflage, Hg. Stefan Schorch und Ernst-Joachim Waschke, BZAW 427 (Berlin: De Gruyter, 2013): 94-106. For a recent overview of the issue including the main bibliography, see Aaron Hornkohl, »Biblical Hebrew: Periodization, « Encyclopedia of Hebrew Language and Linguistics, Vol. I, ed. Geoffrey Khan et al. (Leiden: Brill, 2013): 315-325.

2 See, e.g., the following studies in Diachrony in Biblical Hebrew, ed. Cynthia L. Miller-Naudé and Ziony Zevit (Winona Lake, IN: Eisenbrauns, 2012): B. Elan Dresher, »Methodological Issues in the Dating of Linguistic Forms: Considerations from the Perspective of Contemporary Linguistic Theory«: 19-38; John A. Cook, »Detecting Development in Biblical Hebrew Using Diachronic Typology«: 83-96; Robert D. Holmstedt, »Historical Linguistics and Biblical Hebrew«: 97-124. 3 That Biblical Hebrew is an artificial language similar to Esperanto was argued by Robert North, »Could Hebrew Have Been a Cultic Esperanto?« Zeitschrift für Althebraistik 12 (1999): 202-217. Similarly, although without reference to Esperanto, see Ernst Axel Knauf, »War >BiblischHebräisch eine Sprache? Empirische Gesichtspunkte zur linguistischen Annäherung an die Sprache der althebräischen Literatur«, Zeitschrift für Althebraistik 3 (1990): 11-23.

Anmerkung: Revised version of a lecture presented in a session of the Fachgruppe Altes Testament in der Wissenschaftlichen Gesellschaft für Theologie held in Eisenach, 14 to 17 May 2015. I thank Professor Markus Witte for the invitation to speak in the session, and Professor Jan Gertz for the proposal to publish the text of the lecture in ZAW.

*Kontakt: Jan Joosten, University of Oxford, jan.joosten@orinst.ox.ac.uk 
can take on rather divergent meanings according to the »chronolect « in which they appear. To give only one example, the Hebrew verb עמד means »to be in a standing position « in early texts, but in later texts it also expresses the meaning »to stand up«. Similarly the hiphil stem means »to keep in a standing position" in early texts, but »to raise « only in late texts. ${ }^{4}$ This information is relevant to the interpretation of some passages:

Ex 9,16

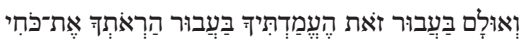

Does this mean: "And indeed for this cause have I raised thee up, for to shew in

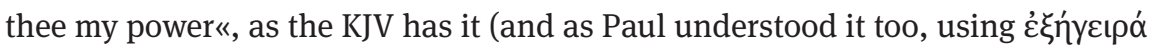
$\sigma \varepsilon » I$ raised you up « in his quotation of the verse in Rom 9,17)? Or does it mean: "This is why I have let you live: to show you my power", as the NRSV has trans-

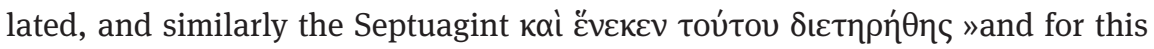

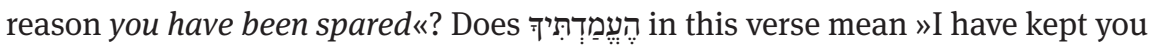
standing « or »I have raised you up«? Historical linguistics can help in deciding on this question: in Exodus, and indeed in the entire Pentateuch, only the first meaning is usual for the hiphil of עמד. The second meaning is attested only in

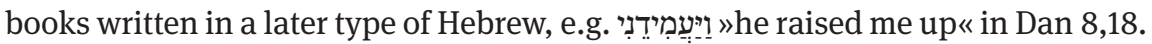
In language-historical perspective, the NRSV and the Septuagint give a good translation of Ex 9,16. The KJV translators, and Paul, mix up different types of Hebrew. $^{5}$

A broad consensus exists among Hebraists as to the basic chronology of Biblical Hebrew. In a diachronic view the biblical corpus falls into two sub-corpora: »classical (or standard) biblical Hebrew« (CBH) as found in Genesis to II Kings, and »late biblical Hebrew« (LBH) as found in Ezra-Nehemiah, Chronicles, Esther, Daniel and Ecclesiastes. CBH and LBH differ systematically in their vocabulary and syntax, and they do so in a way that leaves no doubt as to the relative chronology. LBH is characterized by a profusion of Aramaic loanwords, which can only have come into the language secondarily. LBH also has around 20 loanwords from Persian. ${ }^{6}$ Moreover, the verbal system of LBH is typologically later than that

4 See, e.g., Avi Hurvitz, »The Linguistic Status of Ben Sira as a Link Between Biblical and Mishnaic Hebrew: Lexicographical Aspects, « in The Hebrew of the Dead Sea Scrolls and Ben Sira, ed. Takamitsu Muraoka and John Elwolde, STDJ 26 (Leiden: Brill, 1997): 72-86, on 78-83.

5 For the quotation of Ex 9,16 in Rom 9,17, see Jan Joosten and Menahem Kister, »The New Testament and Rabbinic Hebrew, « in The New Testament and Rabbinic Literature, ed. Reimund Bieringer et al., SJSJ 136 (Leiden: Brill, 2010): 335-350.

6 See Aren Wilson-Wright, »From Persepolis to Jerusalem: A Reevaluation of Old Persian-Hebrew Contact in the Achaemenid Period, «VT 65 (2015): 152-167. 
of $\mathrm{CBH}$ : the participle takes on a greater role, and the »converted « tenses (wayyiqtol and weqatal) are receding. ${ }^{7}$

The differences are so numerous and so systematic that it is difficult to imagine $\mathrm{CBH}$ and $\mathrm{LBH}$ could have been in active use at the same time. They are not mere style forms but real états de langue, an earlier one and a later one. Giving them an absolute date is, of course, much harder than giving them a relative date. Nevertheless, a number of facts indicate at least a rough absolute date:

- $\quad \mathrm{CBH}$ is closely related to the language of Judean inscriptions from the eighth to sixth centuries BCE. ${ }^{8}$ LBH for its part shows up several features that also characterize Qumran Hebrew. ${ }^{9}$

- A number of writings exhibit a mixture of classical and late linguistic features: Jeremiah, Ezekiel, Second Isaiah, Lamentations, Job, Haggai and Zechariah 1-8. ${ }^{10}$ The language of these writings has been termed »transitional Hebrew«. Typologically, it fits between CBH and LBH. Historically, most of the books concerned show strong links to the sixth century BCE.

- The changes reflected in LBH cannot have come about all at once: a longish period has to be postulated between $\mathrm{CBH}$ and $\mathrm{LBH}$ for the latter to develop out of the former.

7 See Jan Joosten, The Verbal System of Biblical Hebrew. A New Synthesis Elaborated on the Basis of Classical Prose, Jerusalem Biblical Studies 10 (Jerusalem: Simor, 2012): 377-409.

8 See Avi Hurvitz, »The Historical Quest for >Ancient Israel and the Linguistic Evidence of the Hebrew Bible: Some Methodological Observations«, VT 47 (1997): 301-315, in particular 307-310; Shmuel Ahituv, W. Randall Garr and Steven E. Fassberg, »Epigraphic Hebrew«, forthcoming in W. Randall Garr and Steven E. Fassberg, Handbook of Biblical Hebrew (Winona Lake, IN: Eisenbrauns).

9 See Elisha Qimron, The Hebrew of the Dead Sea Scrolls (Atlanta, GA: Scholars Press, 1986), 88-97; 116.

10 On Jeremiah, see Aaron D. Hornkohl, Ancient Hebrew Periodization and the Language of the Book of Jeremiah: The Case for a Sixth-Century Date of Composition, Studies in Semitic Languages and Linguistics 74 (Leiden: Brill, 2013); on Ezekiel, see Mark Rooker, Biblical Hebrew in Transition: The Language of the Book of Ezekiel (Sheffield: Sheffield Academic, 1990); on Second Isaiah, see Shalom Paul, "Signs of Late Hebrew in Isaiah 40-66, " in Diachrony in Biblical Hebrew, ed. Cynthia L. Miller-Naudé and Ziony Zevit (Winona Lake, IN: Eisenbrauns, 2012): 293-300; on Lamentations, see Frederick W. Dobbs-Allsopp, »Linguistic Evidence for the Date of Lamentations, « JANES 26 (1998): 1-36; on Job, see Jan Joosten, »Linguistic Clues as to the Date of the Book of Job: A Mediating Position, « in Interested Readers. Essays on the Hebrew Bible in Honor of David J. A. Clines, ed. James K. Aitken et al. (Atlanta, GA: SBL Press, 2013): 347-357; on Haggai, see Gary A. Rendsburg, "Late Biblical Hebrew in the Book of Haggai, « in Language and Nature. Papers Presented to John Huehnergard on the Occasion of His 60th Birthday, ed. Rebecca Hasselbach and Na'ama Pat-El (Chicago, IL: Oriental Institute, 2012): 329-344. 
In light of this evidence, it seems reasonable to date $\mathrm{CBH}$ to a period overlapping the late monarchic period, and LBH to the Persian and early Hellenistic periods.

The diachronic approach to ancient Hebrew was not developed in order to date biblical texts. Once there is a framework, however, textual units can be related to it. Books of uncertain date - Ruth, say, or Jonah - can be scrutinized to determine whether their language is closer to $\mathrm{CBH}$ or LBH. Such an analysis may contribute to a debate on the date of those writings. A schoolbook example of this type of exercise is Avi Hurvitz's monograph on the language of selected Psalms. ${ }^{11}$ Although Psalms are written in poetry, which makes the linguistic analysis more difficult, Hurvitz was able to show that a small number of Psalms (notably Pss 103; 117; 119; 124; 125; 133; 144) are really written in LBH and must therefore be dated to the Second Temple period.

The pre-exilic date of the CBH corpus and the postexilic date of LBH were uncontroversial when they were first proposed, ${ }^{12}$ and remained so until about thirty years ago. More recently, however, the dates accepted in mainline Old-Testament scholarship shifted, or became uncertain. ${ }^{13}$ As a result, a gap appeared between the dates of the literature accepted in biblical studies, and the dates attributed to the phases of Hebrew in Hebrew studies, which most Hebraists have seen no reason to alter. If this gap could be closed, or bridged in any way, the effect would be reassuring. Dating biblical texts is a complex enterprise, but in principle, different criteria should converge on the same date - not point in opposite directions.

The present paper will not contribute much to the question of dating, but rather seek to illustrate one particularly interesting phenomenon in the history of Biblical Hebrew.

11 Avi Hurvitz, The Transition Period in Biblical Hebrew. A Study in Post-Exilic Hebrew and its Implications for the Dating of Psalms (Jerusalem: Mosad Bialik, 1972) [Hebrew].

12 When Gesenius wrote his book on the history of the Hebrew language, many Old Testament scholars still subscribed to the idea of Mosaic authorship of the Pentateuch. However, the critical dates proposed by Wilhelm M. L. de Wette were already gaining the field. See Joosten, »Gesenius«.

13 The tendency to date large parts of the Pentateuch and historical books to the postexilic period was inaugurated by the publications of John Van Seters and Hans Heinrich Schmid on the Pentateuch in the early 1980ies. 


\section{Pseudo-classicisms}

A striking phenomenon characterizing literary Hebrew of the Second Temple period is the re-use of archaic expressions. Late authors use words or idioms they knew from their occurrence in older texts, but whose meaning had come to be forgotten, with a new meaning based on exegesis. Re-use of archaic expressions superficially resembles linguistic evolution: earlier texts exhibit meaning A, while in later texts one finds meaning B. However, the reason for the change in meaning is not foreign influence or natural semantic processes such as generalization or specification. In cases of re-use, the key factor is interpretation of ancient texts. The change is not natural and organic. There is a clean break between meaning A and meaning B. As a result, the language looks classical, because it contains words from $\mathrm{CBH}$, but a closer look shows that the meanings diverge. The language is pseudo-classical.

The phenomenon of pseudo-classicism shows with particular clarity that classical and postclassical Hebrew are not from the same general period. CBH texts became difficult to understand. They were then submitted to exegesis. Subsequently, some of this exegesis became traditional, and in the end, traditional exegesis led to a revivification of words used in the early texts. All this must have taken time.

Pseudo-classicism is observed most clearly in post-biblical writings. It is worthwhile therefore to start studying it there. Once the processes to which it attests have been analysed systematically, some examples in LBH will be explored.

Pseudo-classicisms come into being in several stages: first an old expression is forgotten, then it is reinterpreted, and finally it is used again with the meaning attributed to it in interpretation. These stages deserve to be looked at one by one.

\section{a) Forgotten words}

In the history of the Hebrew language, as in that of every language, many words fell from use and their meaning was forgotten. As a result, texts written in earlier periods were found to contain expressions that were more or less obscure to later readers. Thus Gen 35,16; 48,7 and II Reg 5,19 refer to a measure of distance called

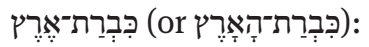

Gen 48,7

And as for me, when I came from Padan, Rachel died by me in the land of Canaan in the way, when yet there was but דִבְרַת to come to Ephrath. 
Modern scholars try to recover the meaning of such words by the help of cognate languages. Tur-Sinai showed convincingly, on the basis of Akkadian bēr qaqqari »land-mile«, that כִּבְרַת is is to be analysed as the preposition כollowed by a noun meaning »mile« in the construct state, and the noun כרכר עland «. ${ }^{14}$ The phrase means: »approximately one land-mile« (»Rachel died when there was still about a land-mile to come to Ephrath«). During the period when $\mathrm{CBH}$ was in active use, the meaning of כִּבְרָת־ ֶֶר must have been widely understood. The expression is used three times and in two distinct contexts: the Genesis passages refer to the same event, but the Elisha story uses it in an entirely different connection. In later times, however, the meaning was forgotten. Eloquent testimony to this oblivion is found in the ancient versions. In the Septuagint, כברת is transcribed in all three passages; the Targums offer various guesses - »stretch of land « (TO), »at the time of harvest« (TN), »when he arrived (in the land)« (SamTg) - and in the Vulgate the expression כִּבְרָת־־ֶר is twice translated as »in spring time«. These ancient translators had no clue as to the meaning of this expression.

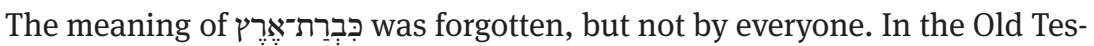

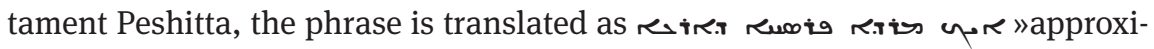
mately a journey of one parasang of land «. The kaph was recognized as a preposition expressing approximation, and ברת was identified as a measure of distance. The parasang is estimated at between five and ten kilometres, the Akkadian bēru at the distance one can walk in two hours. Some scholar in Edessa seems to have had access to a good and old tradition regarding the meaning of the phrase.

The expression כִּבְרָת־־ר is offered here as an example. There are many other words in the Hebrew bible whose meaning was demonstrably forgotten already in Antiquity. ${ }^{15}$

14 Naftali Herz Tur-Sinai (né Harry Torczyner), כברת ארץ, Encyclopedia Miqra’it 4 (Jerusalem: Mosad Bialik, 1963): $11 \mathrm{f}$. See also Ernst Vogt, »Benjamin geboren seine Meileく von Ephrata, « Bib 56 (1975): 30-36.

15 See e.g. Walter Dietrich, »Hebräische Hapaxlegomena in den Samuelbüchern, « in Biblical Lexicology: Hebrew and Greek. Semantics - Exegesis - Translation, ed. Jan Joosten, Eberhard Bons, Regine Hunziker-Rodewald and Romina Vergari, BZAW 443 (Berlin: De Gruyter, 2015): 103-129. As is demonstrated very nicely by Dietrich, rare words tend to cluster in the earliest literary strata of the books of Samuel. 


\section{b) Reinterpretation}

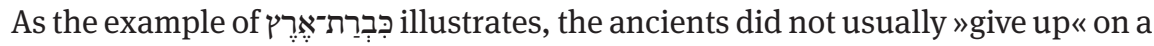
word. When a word occurring in ancient texts had fallen into oblivion, readers and expositors tried to interpret it as best they could. ${ }^{16}$ Many of their interpretations were doubtless successful, whether due to genuine philological competence or to good luck. But other interpretations are unmasked as fanciful by modern-day

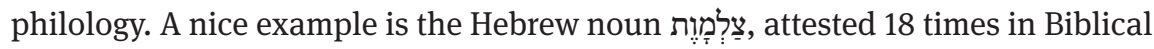
poetry. Originally it must have meant something like »deep darkness «, a meaning that fits all biblical passages where it occurs. ${ }^{17}$ The word derives from the root צלם ״to be obscure«, with the -ut ending typical of abstract nouns. In later times, however, the root fell into disuse and the meaning of the noun derived from it was forgotten. Consequently, the word was analysed as a compound, »shadow of death «, consisting of צל עות ״death «. ${ }^{18}$ The meaning »shadow of death « rests on creative reinterpretation of an old Hebrew word, not on sound tradition. ${ }^{19}$ Yet the interpretation was widely disseminated. The rendering »shadow of death « is found in the Septuagint, Targums, Peshitta and Vulgate. ${ }^{20}$ It also underlies the Masoretic vocalization. It is reasonable to think that most Jews of

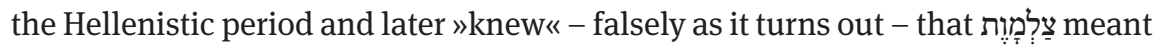
"shadow of death". The meaning »darkness« was recovered only in the Middle Ages on the basis of Arabic. ${ }^{21}$

Many other early words were reinterpreted in ways that did not correspond to their original meaning.

\section{c) Reuse in original compositions}

The most striking thing is what happens next. When a new meaning is attributed to a forgotten word on the basis of exegesis, this sometimes gives the word a new

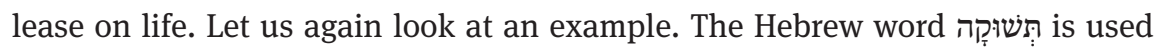

16 In many cases their explanations will have been adequate, thus making their input invisible to us. Only where their guesses diverge from the original meaning is their philology revealed.

17 The word has a precise cognate in Ugaritic $z l m t$ »darkness«.

18 Note that there are no compound nouns in Hebrew, nor in early Semitic in general.

19 See Chaim Cohen, »The Meaning of צלמות >Darkness`: A Study in Philological Method, « in Texts, Temples, and Traditions, ed. Michael V. Fox (Winona Lake, IN: Eisenbrauns, 1996): 287-309. 20 The word is used in $1 \mathrm{QH}^{\mathrm{a}} \mathrm{XIII} 35$, but the poetical context makes it hard to know the meaning the author intended.

21 See in much detail Cohen, »The Meaning of צלמות «. 
twice in Genesis and once in Song of Songs. Etymological and contextual considerations show that it means something like »desire«: »I am my beloved's, and his desire (תְשׁוּקָה) is toward me« (Song 7,11, similarly in Genesis 3,16; 4,7). In the Hellenistic period, however, this meaning seems to have been no longer known. ${ }^{22}$

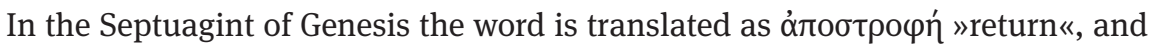
the same interpretation is found in the Targums and the Peshitta, as well as in most of the versions of Cant 7,11.

Now, תִשׁוּקָה also occurs a number of times in the texts recovered from the Qumran caves. Close study of the passages where it occurs indicates its usage differs from the biblical one. Particularly revealing is a passage from the Rule Scroll:

1QS XI 21-22

והואה מצירוק חמר קורץ ולעפר תשוקתו

From the spit (?) of clay he was nipped off, and for clay is his --.

Many translators have taken תשוקה here in the meaning »desire« or »longing«, reading it in the light of Biblical Hebrew. It has been noted, however, that the passage is based on Gen 3,19, according to which the human being will »return (תשוב) to dust«. This suggests that the intended meaning of תשוקה is »return« rather than »desire« in 1 QS XI 22. This conclusion is confirmed by a parallel passage in the Hodayot:

$10 H^{a}$ X 3-4

[from clay] he was nipped off and to dust is his return.

ח̊[מר] קורץ ולעפר תשובתו

It appears, then, that in the Hebrew of the Qumran Scrolls, תשובה are synonyms, both meaning "return «. ${ }^{23}$ The change in meaning, from »desire« to "return«, is not a natural one. The meaning »return« seems to have been attributed to the Hebrew word in the exegesis of Gen 3,16; 4,7. This interpretation was known to the ancient translators and to the authors of the Qumran texts. The latter did not only interpret the word this way, but re-used it in their own writings.

Pseudo-classicisms testify to two distinct processes having to do with the transmission and production of written texts in a religious setting during the

22 Note that in Gen 4,7 Symmachus renders the word as óp $\mu$ ' »impulse, eager desire«, followed by Jerome who renders it appetitus. This probably indicates that in later times the meaning of the word was recovered through close study of the contexts in which it occurred.

23 The word תשוקה occurs with the same meaning in 1QM XIII 12; XV 10; XVII 4 and in some fragmentary texts. 
Second Temple period. Firstly, during this period, scriptural texts were objected to intense and sustained exegetical activity. Although it is difficult to know which texts were considered authoritative in this period, the corpus most probably did overlap with the Pentateuch and Prophetical books as they have come down to us. Rare and ancient words contained in these texts had fallen from use, and were interpreted in light of etymology, context, and religious tradition. Interpretations that seemed fitting were transmitted down the generations, and travelled from one milieu to another. Pseudo-classicisms should not be regarded as isolated mistakes. They reflect the activity of a »school « practising and teaching scriptural exegesis. This fact alone accounts for the multiple attestation of some pseudo-classicisms, which are reflected not only in Qumran Hebrew but also in the Septuagint and other versions or even in the Masoretic vowels.

Secondly, authors of this period attempted to write religious texts in a style similar to that of the earlier texts they had adopted as scripture.

Many other instances of this phenomenon can be found in the Dead Sea scrolls. ${ }^{24}$ Fairly certain examples include the noun שֵ שָחת "pit« reinterpreted as »corruption" (on the basis of the verbal root שחעוֹז ${ }^{25}$ "refuge" reinterpreted

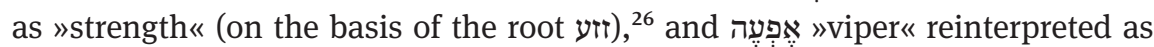
»nothingness « (on the basis, probably, of a scribal mistake in Isa 41,24). ${ }^{27}$

\section{Pseudo-classicisms in LBH}

Pseudo-classicisms can with particular clarity be observed in the Qumran Scrolls. They are frequent and well profiled particularly in the sectarian writings. Several scholars consider pseudo-classicism an essential characteristic of Qumran Hebrew. It is certainly no coincidence that they were first identified there. ${ }^{28}$ The

\footnotetext{
24 See Jan Joosten, »Pseudo-classicisms in Late Biblical Hebrew, in Ben Sira, and in Qumran Hebrew, « in Sirach, Scrolls and Sages. Proceedings of a Second International Symposium on the Hebrew of the Dead Sea Scrolls, Ben Sira, and the Mishnah, held at Leiden University, 15-17 December 1997, ed. Takamitsu Muraoka and John F. Elwolde (Leiden, Brill, 1999): 146-159.

25 See Preben Wernberg-Møller, The Manual of Discipline (Brill: Leiden, 1957), 81.

26 See Jan Joosten, »The Knowledge and Use of Hebrew in the Hellenistic Period. Qumran and the Septuagint, « in Diggers at the Well. Proceedings of a Third International Symposium on the Hebrew of the Dead Sea Scrolls and Ben Sira, ed. Takamitsu Muraoka and John F. Elwolde (Leiden: Brill, 2000): 115-130.

27 See Joosten, »Pseudo-classicisms«: $150 \mathrm{f}$. For a different treatment, see Max Rogland, »Eggs and Vipers in Isaiah 59 and the Qumran Hodayot, « RdQ 97 (2011): 3-16.

28 Examples are particularly prominent in the Hodayoth. Several instances of the phenomenon were pointed out in the early phases of interpretation. See e.g. above note 24.
} 
phenomenon is not limited to $\mathrm{QH}$ however. ${ }^{29}$ Notably, it also operates in some of the later biblical books. Although the examples are less numerous, the phenomenon is essentially similar. Two examples from Chronicles will illustrate:

\section{מלא יד}

In the Pentateuch and Former Prophets, the expression »to fill someone's hand « means »to ordain to a sacred office . $^{30}$

\section{Jud 17,5}

»(Micah) had a shrine, and he made an ephod and teraphim, and installed

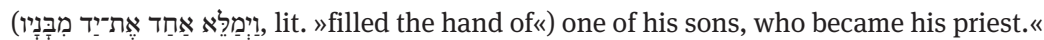

The meaning of the idiomatic expression »to fill someone's hands « appears to have been widely (though not universally ${ }^{31}$ ) forgotten during the late Persian period. One meaning that emerged in the exegetical tradition is: »to give offerings «. This interpretation is attested in the Targums. The end of the verse from Jud 17,5 quoted above is translated in Targum Jonathan: »He brought the offering of one of his sons (וקריב ית קרבן חד מבנוהי), who became his priest«, and this is the standard translation of the expression in all the Jewish Targums. Probably this interpretation was based on the meaning of the component parts of the idiomatic expression. With this meaning, the word was used anew in Chronicles (I Chr 29,5; II Chr 13,9; 29,31).

Modern translations and dictionaries tend to treat the Chronicles passages the same way as the others. Attention to the context shows, however, that this is problematic. ${ }^{32}$ In I Chr 29,5, David appeals to the people to give gold, silver and precious stones for the building of the temple. After having enumerated all he is willing to donate himself, he goes on to say: "Who then will offer willingly, filling their hands today to the Lord? « The NRSV has rendered this »Who then will offer willingly, consecrating themselves ... « but there is no contextual warrant for this translation. The Israelites who contribute to the building of the temple

29 For pseudo-classicisms in later Hebrew see Jan Joosten, »Classicism: Biblical Hebrew, «Encyclopedia of Hebrew Language and Linguistics, Vol. I, ed. Geoffrey Khan et al. (Leiden: Brill, 2013): 454.

30 See also Ex 28,41; 29,9.29.33.35; Lev 8,33; 16,32; 21,10; Num 3,3; Jud 17,5.12; I Reg 13,33. In Ez 43,26 the expression refers to the consecration of an altar.

31 The expression is correctly interpreted as referring to consecration in the Septuagint. It is used with the same meaning in the Temple Scroll (e.g. 11QT XXXV 6) and in Ben Sira 45,15, although in both writings in close dependence on biblical models.

32 See Meir Paran, Forms of the Priestly Style in the Pentateuch (Jerusalem: Magnes, 1989), $283 \mathrm{f}$. 
are not priests, nor are they trying to become priests, not even metaphorically. The passage is concerned with donations. The expression »to fill their hand « is a figure implying the giving of offerings. One might render the half verse: »Who then will offer willingly, filling their hands today with gifts for the Lord? « The two other attestations, in II Chr 13,9 and II Chr 29,31, also imply giving, not ordination. ${ }^{33}$

The divergent usage in Chronicles does not result from natural development of the language. Rather, the same process is at work that we found underlying Qumran Hebrew usage. ${ }^{34}$ An interpretation established in the exegetical tradition leads to a renewed use of an archaic expression.

\section{לבוא+ n. loc.}

The geographical name לִּוֹא חְזָמָת is found 11 times in the Hebrew Bible. Originally it designated a place named Lebo situated in the land of Hamath. ${ }^{35}$ In later times, however, this location was no longer known and the first part of the name was reinterpreted as the preposition ל followed by the infinitive of בוא ^to come«. Thus

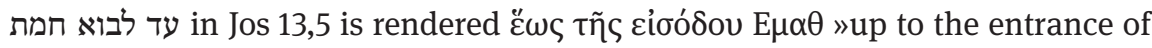
Emath « in the Septuagint. Similar renderings are found elsewhere in the Septuagint, ${ }^{36}$ as well as in the other ancient versions. Only in the twentieth century was the true meaning of the name rediscovered thanks to close study of cuneiform and hieroglyphic texts mentioning the city of Lab'u in the land of Hamath. ${ }^{37}$

33 In one passage, the notion of ordination does come up, but it is doubtful whether the idiom "to fill the hand « expresses it, II Chr 13,9»Whoever comes, filling his hand with a young bull or seven rams, will be a priest of what are no gods." As the reference to the "young bull or seven rams « shows, the "filling of the hand « concerns the gift the apostate Israelite brings in order to be induced into the priesthood. Those who »fill their hand « with a big enough gift are ordained as priests. The gift is a prerequisite to the ordination, not the ordination itself. None of the passages in the Pentateuch or Former Prophets mentions such a gift, and none seems to be implied there.

34 The line-up of the data is messier in this case than in the one from Qumran Hebrew discussed above. The attestation of the Targums is much later than that of Chronicles. Nevertheless, there can be little doubt that the phenomenon is essentially the same. Both the Chronicler and the Qumran authors re-used archaic expressions in their effort to imitate the style of older writings they regarded as scripture.

35 See Yohanan Aharoni, The Land of the Bible. A Historical Geogaphy (London: Burns \& Oates, $\left.{ }^{2} 1979\right), 72$.

36 The only exception seems to be Jud 3,3, where the entire name is transcribed in the Septuagint (both B and A).

37 The original discovery was made by Karl Elliger, see Aharoni, Land of the Bible, 80. 
The history of the expression throws an interesting light on a passage in the book of Chronicles:

II Chr 26,8

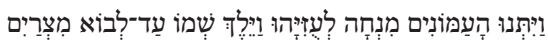
And the Ammonites gave gifts to Uzziah: and his name spread abroad even to the entering in of Egypt.

Nothing is known of a city called Lebo in Egypt. It appears therefore that the 3. לבוא חמת לבוא מצרים owes its origin to reanalysis of the expression The author of Chronicles analysed the old geographical name in the same way as the Septuagint translators, and took עד לבוא as an idiomatic expression meaning "unto «. ${ }^{39}$ He then used it in a completely different context, thus revealing his understanding of the expression, which was at variance with its original meaning.

Although pseudo-classicisms are less thickly sown in the LBH corpus than in QH, their number is not negligible. Several other examples have been pointed out. The expression דבר על לב has an idiomatic meaning »to comfort (?)« in Genesis, Judges, Ruth, Hosea and Second Isaiah, but in II Chr 32,6 it is used in reference to actual speech, and followed by direct discourse. ${ }^{40}$ The noun מגרש means "pasture land « in the Pentateuch, Joshua and Ezekiel, but is used in the meaning "Levitical cities « in Chronicles. ${ }^{41}$ The latter meaning no doubt reflects exegesis of earlier passages: the word is practically limited to discussion of the pasture land set aside for Levites around the Levitical cities. ${ }^{42}$

These examples show that the dividing line between classical and post-classical Hebrew does not run between the Hebrew Bible and the Qumran writings, but within the biblical corpus itself. Chronicles and Ezra-Nehemiah essentially align with Qumran Hebrew against older texts as found in the Pentateuch and the Prophets.

38 The latter also occurs in Chronicles, see I Chr 13,5; II Chr 7,8.

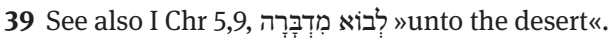

40 See Jean-Marc Babut, Les expressions idiomatiques de l'hébreu biblique, Cahiers de la Revue Biblique 33 (Paris: Gabalda, 1995), 84-87.

41 Sarah Japhet, »The Supposed Common Authorship of Chronicles and Ezra-Nehemia Investigated Anew, «VT 18 (1968): 330-371, in particular 348-350.

42 For more examples see Joosten, »Pseudo-classicisms.» 


\section{Conclusions}

Several words and expressions turn up in ancient Hebrew texts with two sets of meanings: one old, genuine, and more often than not paralleled in cognate languages, and one late and secondary, with echoes in the ancient versions and exegetical writings. To all appearances, these are words that were reused in a meaning based on scriptural exegesis after their original meaning was forgotten. They are »dying and rising " words, taking their original meaning with them into the grave and resurrecting with a new meaning established in the course of textual interpretation. The new usage superficially resembles classical Biblical Hebrew, but a closer look reveals essential differences.

Pseudo-classicisms show that scriptural interpretation had become an institution at the time the late biblical books such as Chronicles and Ezra-Nehemiah were composed. They also show that interpretation led to re-appropriation, with later authors making a strong claim to continuity with earlier writings that had become authoritative.

They provide strong evidence of diachronic evolution in ancient Hebrew. $\mathrm{CBH}$ and LBH are not the same language, nor even contiguous chronolects: they are separated by a period of time long enough to allow for the forgetting of many expressions, their reinterpretation in an unrelated way, and their revivification with the new meaning.

Abstract: Several words and expressions turn up in ancient Hebrew texts with two sets of meanings: one old, genuine, and more often than not paralleled in cognate languages, and one late and secondary, with echoes in the ancient versions and exegetical writings. To all appearances, these are words that were reused in a meaning based on scriptural exegesis after their original meaning was forgotten. Pseudo-classicisms show that scriptural interpretation had become an institution at the time of the late biblical books. They also show that interpretation led to re-appropriation, with later authors making a strong claim to continuity with earlier writings that had become authoritative. They provide strong evidence of diachronic evolution in ancient Hebrew. $\mathrm{CBH}$ and LBH are not the same language, nor even contiguous chronolects: they are separated by a period of time long enough to allow for the forgetting of many expressions, their reinterpretation in an unrelated way, and their revivification with the new meaning.

Résumé: Plusieurs termes et expressions apparaissent en hébreu ancien avec deux types de sens: un ancien, authentique et le plus souvent sans parallèle dans les langues connexes, et l'autre tardif et secondaire, avec des échos dans les ver- 
sions anciennes et les textes exégétiques. Selon toute vraisemblance, ces termes ont été réutilisés dans un sens basé sur une exégèse scripturaire après que leur sens original ait été oublié. Les pseudo-classicismes montrent que l'interprétation scripturaire est devenue une institution au temps des livres bibliques tardifs. Ils montrent aussi que l'interprétation conduit à la réappropriation, les auteurs plus tardifs revendiquant fortement une continuité avec les écrits plus anciens qui sont devenus autoritaires. Ils apportent une indication solide d'une évolution diachronique dans l'hébreu ancien. L'hébreu classique et l'hébreu tardif de la Bible ne constituent pas une même langue, ni même des chronolectes contigus: ils sont séparés par une période de temps suffisamment longue pour permettre l'oubli de beaucoup d'expressions, leur réinterprétation dans un sens non-apparenté, et leur revivification à l'aide du nouveau sens.

Zusammenfassung: Zahlreiche Wörter und Ausdrücke erscheinen in althebräischen Texten in zweierlei Bedeutung: einer alten, genuinen, meist nicht parallel zu verwandten Sprachen, und einer späten und sekundären, mit Anklängen an die alten Übersetzungen und exegetischen Schriften. Allem Anschein nach sind dies Worte, die nachdem die ursprüngliche Bedeutung vergessen wurde, in einer Bedeutung wiederverwendet wurden, die auf der Schriftexegese beruht. PseudoKlassizismen zeigen, dass die Schriftinterpretation zur Zeit der späten biblischen Bücher zu einer Institution geworden war. Sie zeigen auch, dass die Interpretation zu einer Wiederaneignung führt, wobei spätere Verfasser stark Kontinuität zu früheren Schriften forderten, die bereits als autoritativ galten. Sie liefern deutliche Hinweise zur diachronen Entwicklung des Althebräischen. CBH und LBH bilden nicht die gleiche Sprache, noch nicht einmal zusammenhängende Chronolekte: Sie sind durch eine Zeitspanne getrennt, die lang genug war, um es zu ermöglichen, dass viele Ausdrücke vergessen, in einer unabhängigen Weise neuinterpretiert und in neuer Bedeutung wiederbelebt wurden. 